\title{
Cure or Protection? The meaning of smallpox inoculation, ca 1750-1775
}

\author{
ANNE ERIKSEN* \\ Department of Culture Studies and Oriental Languages, University of Oslo, \\ P.O. Box 1010 Blindern, 0315 Oslo, Norway
}

\begin{abstract}
The idea that smallpox could be eradicated was not necessarily the ultimate aim when inoculation was introduced in Europe in the 1720s. This potentiality was not clearly articulated as an aim until the end of the eighteenth century. This article argues that during most of the eighteenth century, the main aim of inoculation was to lead people as safely as possible through what was regarded as an unavoidable disease. Inoculation became safer, simpler and less expensive from the 1760s, but the changing ideas about its potentiality had more complex roots. A new understanding was produced through an interaction between inoculation practice, more general medical theory and developments within probabilistic thinking and political arithmetic. The first part of the article explores how smallpox inoculation was incorporated into existing medical thinking based on traditional humoral pathology. Inoculation was a new technology, but as it was perceived in the early eighteenth century, the innovation did not first and foremost concern the medical principles of the treatment. The second part of the article investigates arguments about why and when to inoculate: what kind of remedy was inoculation for eighteenth-century agents? The article concludes with a discussion on changes emerging towards the end of the century, and relates them to developments during the preceding decades rather than seeing them as inspired precursors of events and ideas to come.
\end{abstract}

Keywords: Smallpox inoculation, Eighteenth century, Humoral pathology, Reluctance to change

What was the meaning of eighteenth-century smallpox inoculation? Traditional medical history used to present a continuity from inoculation to Jenner's vaccine in 1798 and subsequently to the national vaccination programmes of the nineteenth and twentieth centuries, ending in total triumph with the global eradication of smallpox in the 1980s. ${ }^{1}$

\footnotetext{
* Email address for correspondence: anne.eriksen@ikos.uio.no

${ }^{1}$ For traditional presentations of the history of smallpox, see, for instance, Peter Razzell, The Conquest of Smallpox. The Impact of Inoculation on Smallpox Mortality in Eighteenth Century Britain (Firle: Caliban Books, 1977); Ian Glynn and Jennifer Glynn, The Life and Death of Smallpox (London: Profile Books, 2004); Gareth Williams, Angel of Death. The Story of Smallpox (Basingstoke: Palgrave Macmillan, 2010). More modern perspectives have been offered by scholars working on non-European material. See, for instance, Harish Naraindas, 'Care, Welfare and Treason: The Advent of Vaccination in the 19th Century', Contributions to Indian Sociology, 32 (1998) 67-96; Niels Brimnes, 'Variolation, Vaccination and Popular Resistance in Early Colonial South India', Medical History, 48 (2004) 199-228.
} 
The new medical history from the 1970s onwards has done much to change the general perspectives claiming a linear progressive development in medicine. ${ }^{2}$ As early as in 1985, Roy Porter argued the importance of studying beliefs about illness and health, situated in their historical contexts. ${ }^{3}$ While Porter drew attention chiefly towards beliefs among the laity, recent studies in the history of technology and science have also pointed to the influence of cultural factors among scientists themselves. Not least can this be claimed to be relevant in the case of medicine, situated as it is between science and social practice. Ludmila Jordanova contrasts this modern interest in investigating meanings, beliefs and interest with traditional history of science and medicine, saying that 'in a progressivist narrative, the search for truth was told in terms of blind alleys and right answers; the model was a journey, and the main emphasis was on content'. ${ }^{4}$ She goes on to point out that few questions were asked about mediating processes, or about 'how problems requiring explanations were defined'. 5 The new medical history, on the other hand, was, as Jordanova argues, shaped by a number of theoretical influences which may all be grouped as 'social constructionist'. This implied a shifting of focus from the content of the 'right' answers to the processes by which knowledge - including scientific knowledge - is produced and negotiated. Jordanova describes this by saying that 'between the material world and our representations of it there now appeared to be a space, which it was the job of historians (and sociologists and philosophers) to examine'. ${ }^{6}$ This article will enter such a space, and ask how smallpox and smallpox inoculation were understood in the second part of the eighteenth century.

The idea that smallpox could be conquered, even eradicated, was not a necessary companion to the new method when it was introduced in Europe. This potentiality only gradually emerged and was not clearly articulated until the end of the eighteenth century. The main focus of the present article will be the years approximately between 1750 and 1775. Often called the second phase of smallpox inoculation in Europe (after its introduction in the 1720s), this period saw important changes in the way inoculation was carried out. The method became both safer, simpler and less expensive than before. The changes made new ideas possible, but it is important that they were not initiated by the ideas and projects which they later inspired. It also would be overly simplistic to view changing understandings as mere reflections of improved method. The new ideas had more complex roots than technical improvements alone. This article will argue that the slowly changing understanding of the potentialities of inoculation was produced by an interaction between inoculation practice, more general medical theory and developments within probabilistic thinking and political arithmetic.

Because the idea of the article is not to discuss the actual practice of inoculation, some issues that have figured prominently in historical research on inoculation will not be touched upon. This concerns the questions of mortality rates and population growth, as well as popular resistance against inoculation. Moreover, the article will discuss a period before the more extensive state initiatives to combat smallpox epidemics had

${ }^{2}$ Cf. Mary Lindemann, Medicine and Society in Early Modern Europe (Cambridge: Cambridge University Press, 2010).

${ }^{3}$ Roy Porter (ed.), Patients and Practitioners. Lay Perceptions of Medicine in Pre-industrial Society, (Cambridge: Cambridge University Press, 1985).

${ }^{4}$ Ludmila Jordanova, 'The Social Construction of Medical Knowledge', Social History of Medicine, 07/03 (1995), 361-81.

${ }^{5}$ Ibid. (note 4), 363 .

${ }^{6}$ Ibid. (note 4), 363. 
been launched, and thus not go into the idea of public health as it emerged through such programmes. What rather is at stake in the following is the meaning of smallpox inoculation to its eighteenth-century advocates and practitioners. What was inoculation to them? As will appear from the following investigation, this question concerns the medical workings of the new remedy, but also its religious and ethical implications. The meaning of inoculation moreover relates to understandings of chance, luck, hazard and risk, and to the changing conceptualisation of the relation between the individual subject and the population at large.

The method chosen to explore this is a close reading of influential texts on inoculation, produced in three different European countries. They represent voices in a public debate on why, when and, to some degree, how to inoculate.

As a method of analysis, close reading insists on taking seriously what goes on in the text. The aim is not primarily to detect the intentions of the authors or the influence of their historical contexts, but to study texts as historical realities carrying meaning in themselves. The texts to be investigated here reflect how inoculation was spoken of, what kind of metaphors it was surrounded by, how disease and epidemics were conceptualised. Moreover, they provide the possibility of understanding something about the self-evident premises of the arguments. What is not said, what is not made an issue in these text - because it was unthinkable, or because it was self-evident? To understand the motives and ideas of eighteenth-century medical agents, studies of technology and medical practices alone are not sufficient. The ways the disease and its remedies were spoken of and turned into arguments of a public debate are equally important.

The first part of the article explores how smallpox inoculation in Europe was incorporated into existing medical thinking based on traditional humoral pathology. Inoculation was a new technology, and radically so, but as it was perceived in the eighteenth century the radicality did not first and foremost concern the medical principles of the treatment. The middle part of the article investigates arguments as to why and when to employ the new technology. What kind of remedy was inoculation to mid-eighteenth century agents? What kind of situations made its use relevant, and what was the expected outcome? The article concludes with a discussion on changes that emerged towards the end of the century, relating them to developments during the preceding decades rather than seeing them as inspired precursors of events and ideas to come.

The material for this study is taken from England, France and Denmark-Norway. England was the first country in Europe where inoculation was introduced from the Middle East, and also the country where it was most generally used. Comparing England to France, where inoculation never became common practice and powerful institutions like the Sorbonne even pronounced themselves against it, it appears obvious that even the arguments in favour of the method differed. One reason for this difference, as Andrea A. Rusnock has pointed out, was that in England the physicians themselves advocated the method, which made it possible to unite practical experience with theoretical argument. In France, local corporations controlled medical practice to a far greater extent, and most of them opposed inoculation for a longer period of time. Here the method was advocated by philosophes who were not physicians, or by physicians who were not French. ${ }^{7}$ Both countries hold central positions in the history of European smallpox inoculation.

\footnotetext{
${ }^{7}$ Brimnes, op. cit. (note 1); Andrea A. Rusnock, Vital Accounts. Quantifying Health and Population in Eighteenth Century England and France (Cambridge: Cambridge University Press, 2002), 10f, 75. Based on this argument, the Swiss Tissot and the Italian Butini and Gatti are reckoned as 'French' in this context: they published in French, and France was the scene of much of their influence.
} 
Denmark, and not least its northern province Norway, represents a European periphery. The first inoculations in this twin monarchy appear to have taken place in Trondheim (Norway) in 1754. In the capital Copenhagen, a royal inoculation house was established in 1755, but met with little success and closed down after just five years. Apart from this, inoculation in Denmark-Norway seems to have occurred only sporadically and due to private and in some cases lay initiatives. ${ }^{8}$ Pro-inoculation debate was strongly influenced by texts in English and French, some of which were read in the original, others translated. The earliest text on inoculation to have been published in Denmark-Norway was by J.-A. Butini, originally published in 1752 and translated from French in 1753. La Condamine's internationally influential pamphlet appeared in Danish in 1755, one year after the French original. ${ }^{9}$

The texts examined in this article are two medical treatises, written by the English physician J. Kirkpatrick and the Danish professor of medicine Chr. Friis Rottböll, respectively. ${ }^{10}$ Together with a short article by the Swedish physician L. Montin, these texts discuss medical theory concerning smallpox and the effect of inoculation. ${ }^{11}$ The texts by the Swiss physicians J.-A. Butini and S.A.D. Tissot, the Italian Angelo Gatti and the English Thomas Dimsdale are manuals, giving instructions on how to carry out inoculation. ${ }^{12}$ They cite arguments in defence of the new technology, but do not enter into discussions on how it works. The texts by Cramer and Bredal, la Condamine, Tronchin and Smith, finally, all promote inoculation by explaining its advantages and also by answering the objections that were most commonly raised against it. ${ }^{13}$

The aim of the investigation is not to elaborate on national differences, but rather to show how the inoculation debate was fairly international. Influential texts circulated widely and crossed national borders. Pro-inoculation arguments were quoted extensively, and long passages of texts by one author could be incorporated into that of another. Works advocating inoculation constituted an intertextual network, explicitly and implicitly referring to each other. In this network, the three countries of this investigation held different roles. All produced texts and arguments that circulated. The English and French

${ }^{8}$ Anne Eriksen, 'A Case of Exemplarity: C.F. Rottböll's History of Smallpox Inoculation in Denmark-Norway, 1766', Scandinavian Journal of History, 35, 4 (2010), 351-70; Peter Sköld, The Two Faces of Smallpox. A Disease and its Prevention in Eighteenth and Nineteenth Century Sweden (Umeå, Umeå University, 1996).

${ }^{9}$ Jean-Antoine Butini, Afhandling om de ved Indpropningen tilbragte Børne-kopper. Formedelst dens almindelige Nytte oversat af det Franske idet Danske Sprog (Copenhagen: Frans Chr. Mumme, 1753), CharlesMarie de La Condamine, Kort Afhandling om Smaa-Koppernes Indpropning, ved Mr. de la Condamine, til Fadernelandets formodentlige Nytte af Fransk oversat i Dansk (Copenhagen: A.H.J. Godiche, 1755), Danish translation of the Mémoire from 1754.

${ }^{10}$ J. Kirkpatrick, The Analysis of Inoculation. Comprizing the History, Theory, and Practice of it: With an Occasional Consideration of the most Remarkable Appearances in the Small Pox (London: J. Millan, J. Buckland, and R. Griffiths, 1754); Christen Friis Rottböll, Afhandling om Smaae-Kopperne, deelt udi tvende Parter (Copenhagen: 1766).

${ }^{11}$ Lars Montin, 'Anmerkninger ved den nye Koppodnings Maade', Det Kongelige Norske Videnskabers Selskabs Skrifter, 5 (1774), 159-76.

12 S.A.D. Tissot, L'inoculation justifiée, ou Dissertation pratique et apologetique sur cette méthode; avec un essai sur la тиё de la voix (Lausanne: Chez Marc-Michel Bousquet, 1754); Angelo Gatti, Réfléxions sur les Préjugés qui s'oppose aus le Progres et á la Perfection de l'Inoculation (Brussels: 1764); Thomas Dimsdale, The Present Method of Inoculating for the Small-pox. To which are added, Some Experiments, Instituted with a View to Discover the Effects of a Similar Treatment in the Natural Small-Pox, 6th ed., corrected (London: 1772). 13 J.A. Cramer, Afhandling om Smaae-Koppernes Indpodning eller Inoculationen [...]. Translation and Introduction by N.K. Bredal (Trondheim: 1762); Théodore Tronchin, 'Inoculation' in Encyclopedie, ou Dictionnaire raisonné des sciences, des arts et des métiers, 8 (1765); A. Chr. Smith, En kort Afhandling om Børnekoppernes Indpodning, til Opmuntring for dens Brug isar blandt den norske Almue (Copenhagen: 1773). 
texts had international influence, the Danish and Norwegian probably merely national. Including material from this part of Europe nonetheless adds to our general knowledge about the history of inoculation. It demonstrates the range and significance of ideas and literature from the larger countries, but it also shows that the time lag was small. Despite their role mainly as receivers of ideas, the physicians and intellectuals in the northern periphery were well oriented, quick to import novelties and to relate themselves to international debates.

All the texts have been influential. They set the debates and shaped opinion, though in different contexts. Some of their authors, like Dimsdale, la Condamine and Tissot, were men of international renown. As a general trait, it may also be worth noting that medical men were not the only ones to contribute to the inoculations debate. Other men of letters and enlightened philosophy took part, which is an indication that inoculation was not only considered to be a matter of medicine but also concerned the welfare of society at large. On the other hand, it is equally interesting to note that no statesmen or men of political influence are to be found among the authors. In all three countries there were only few and mostly weak attempts at organising larger public programs of inoculation in this period, and they do not seem to have resulted in texts that can be taken to indicate pro-inoculation engagements or ideas on the official level of the state.

\section{A New Technology}

Inoculation was introduced into Europe from the Middle East in 1718. Papers by the two physicians E. Timoni and G. Pilarini, published in Philosophical Transactions in 1714, made the technology known to savants. The iconic figure of European inoculation history is nonetheless Lady Mary Wortley Montague. The wife of the English ambassador in Constantinople, she had her young son treated in 1718. When the family returned to England, his sister was inoculated by the surgeon Maitland in 1721. Not least after Lady Mary had convinced the Princess of Wales to have her children inoculated as well, and experiments to check the safety of the method had been carried out on seven prisoners from Newgate Prison, the innovation became the talk of the town.

In 1722 inoculation was heavily condemned for religious reasons by the Reverend Edmund Massey. Inflicting disease was a tool of God, not of humans, he declared. Massey identified the scourge cast by the Lord on Job as smallpox, and denounced inoculation as diabolical. The arguments were answered by Maitland, and soon also by men of the Church. Refuting the religiously based arguments launched by Massey and others nonetheless remained a staple element of pro-inoculation literature throughout the century, in England and elsewhere. The defenders put much energy into not only denouncing the attack, but also presenting pro-inoculation arguments of a religious kind. Most fundamental was the claim that inoculation was a gift from God, given to man to enable him to protect himself. What was sinful was not to inoculate, but to abstain from it, as this meant refusing God's gift. Inoculation was also defended as a parental responsibility. Not to inoculate one's children was to neglect the duty to protect them. Moreover, by way of saving lives, inoculation would contribute to population growth, which also agreed with the wishes of God (and contemporary economic thought). The earliest pro-inoculation text published in Norway was a translation of an article by the German theologian Johann Andreas Cramer from 1759. In his defence against the religiously based objections, Cramer drew heavily on the ideas of the German demographer Johann Peter Süßmilch, who saw population growth as God's will. Hence, inoculation became a means to comply with divine will, while not protecting one's children in this way was regarded a sin of 
omission. ${ }^{14}$ This argument became a staple element in the pro-inoculation discourse in Denmark-Norway, where a number of subsequent publications reproduced substantial parts of Cramer's text verbatim.

Another, less biblically based objection was that inflicting a potentially fatal disease on healthy persons who might otherwise never be attacked by it was not ethically defensible. Advocates of inoculation responded that hardly anybody escaped smallpox during his or her life, and that the disease normally was even more dangerous when contracted at a mature age. In comparison, inoculation brought on a mild, controlled and usually harmless case of the disease.

The longevity of the debate and the numerous arguments indicate the significance of the religious and ethical challenge posed by inoculation. Even if some Enlightenment radicals would ridicule biblical arguments of the kind presented by Massey, religious and ethical considerations obviously remained an issue that was not to be treated lightly. Among the twelve objections against inoculation discussed by the Swiss physician S.A.D. Tissot in his L'inoculation justifiée from 1754, the first six concern ethical and religious arguments. ${ }^{15}$ The article on inoculation written by the Swiss physician Théodore Tronchin for the Encyclopédie presents altogether thirteen objections to inoculation, the last seven of which are religious and ethical. ${ }^{16}$ In his Analysis of Inoculation, mainly a medical treatise, the British physician James Kirkpatrick presents and counters the religious and ethical objections in the preface. His arguments in defence of the method are in part religious - inoculation is a gift from God - and consist in part of references to past medical authorities who undoubtedly would have been in favour of inoculation and would have acknowledged its providential origin had they only known about it, he declares. ${ }^{17}$ Inoculation was radically new in European medicine, and obviously also experienced as such. However, taking eighteenth-century public arguments seriously, as they were presented in the public debate and in inoculation literature, it appears that what was felt to represent something dramatically different from traditional medicine were the religious and ethical implications rather than the medical aspects. Defending or advocating inoculation meant countering these arguments just as much as entering into a medical discussion.

Parallel to this, and supporting the argument, discussions of how inoculation worked are relatively scarce. Texts trying to explain how the new remedy worked and what its active principles were normally did so within the frames of traditional, philosophical medicine. Inoculation was explained as a treatment working along the same lines as other cures and remedies. Even if it was a novelty in Europe, it was not perceived as a challenge to traditional medical principles. It was surprisingly effective and represented a far better remedy in cases of smallpox epidemics than any other cure or method, but it was not originally seen as fundamentally different from established medicine.

One reason for this was that inoculation was not necessarily perceived as a means to prevent smallpox, but rather as a way of producing a mild and benign case of the disease. The Encyclopédie defines it as 'The operation by which smallpox is artificially communicated, with the aim of preventing the dangers and damages caused by this disease

\footnotetext{
${ }^{14}$ Cramer lived and worked in Copenhagen, with close connections to the court. The article was first published in his journal Der Nordische Aufseher in 1758. Cramer, op. cit. (note 13).

15 Tissot, op. cit. (note 12), 84ff.

16 Tronchin, op. cit. (note 13).

${ }^{17}$ Kirkpatrick, op. cit. (note 10), ix ff.
} 
when it is contracted in the normal fashion' ${ }^{18}$ The Danish physician C.F. Rottböll calls it the best way to cure smallpox, and the Norwegian vicar A. Smith calls it a medication. ${ }^{19}$ Tissot's main argument in favour of inoculation was the possibility it gave of controlling the course of the disease. Smallpox in itself was a mild and not very dangerous kind of disease, he contended. What made it lethal were the circumstances. The age of the patient and his or her constitution, as well as the time of year and the weather conditions, not least the air, all contributed to risk, uncertainty and malignant cases. Inoculation solved these problems, as it made it possible to choose the most suitable age and season and to prepare the patients for it in the ways their individual constitutions demanded. ${ }^{20}$ Nonetheless, Tissot also warned against measures that might make the illness too light - in such cases inoculation will not protect against further attacks of the disease, he maintained. ${ }^{21}$ The idea that smallpox was not really a dangerous disease was not widespread, but the understanding that one of the main advantages of inoculation was the possibility of choosing when to get ill, and to prepare for it, is expressed by a majority of the authors advocating the method.

Scholars working on the history of vaccination in nineteenth-century India have argued that the reason why the modern practice of vaccination did not easily supplant the older variolation (inoculation), was that while the former worked as a prophylactic, the latter was conceived of as part of a therapeutics. Its context of religious ritual was long seen as the explanation for the Indian preference for variolation and corresponding reluctance toward vaccination. More recent research has recast this debate in new terms. Rather than presenting an opposition between the indigenous, religious and 'superstitious' tradition on the one hand, and the European, scientific and effective practice on the other, two different approaches to the challenge raised by smallpox are now described: one therapeutic, the other prophylactic. $^{22}$ Traditional medical history has tended to see European eighteenthcentury inoculation as a prophylactic. Close reading of texts from the period show it rather to be part of a therapeutics. Its important difference from the Indian parallel, however, is that the 'ritual context' of the European treatment was not religion, but learned medicine itself.

The great emphasis that was put on preparations is an important key to this medical understanding. Standard texts on inoculation procedure were usually structured in three phases. The first concerned preparation, which meant both choosing the most suitable time and preparing the patient. The next phase treated the insertion of variolous matter, while the final phase included the course of the subsequent disease and the care of the patient.

The issue of time related in part to the age of the person to be treated. Infants were normally not inoculated, and the minimum age was discussed. In the case of an epidemic, parents were often anxious to have even their newborn treated, but most inoculators set a minimum age of at least two years. ${ }^{23}$ The advisability of inoculating adults was also discussed. Even here an epidemic could dispel theoretically based concerns about

\footnotetext{
18 [l'operation par laquelle on communique artificiellement la petite vérole, dans la vue de prévenir le danger \& les ravages de cette maladie contractée naturellement.] Tronchin, op. cit. (note 13).

${ }^{19}$ Rottböll, op. cit. (note 10), 80; Smith, op. cit. (note 13), 2.

20 Tissot, op. cit. (note 12), $10 \mathrm{ff}$.

21 Tissot, op. cit. (note 12), 148.

22 Naraindas, op. cit. (note 1), 70f; Frédérique Apffel Marglin, Smallpox in Two Systems of Knowledge, WIDER Working Papers no. 17, 1987.

${ }^{23}$ For instance, Kirkpatrick, op. cit. (note 10), 171ff; Tissot, op. cit. (note 12), 39.
} 
treating individuals over thirty years of age. It was generally recommended not to inoculate menstruating or pregnant women. ${ }^{24}$ For the time of year, spring and autumn were recommended, being neither too cold nor too hot. It was also important to choose a period without the threat of other perilous diseases. The preoccupation with weather, season and temperature can be understood as part of eighteenth-century neo-Hippocratic medicine and its interest in the 'non-natural things'. Above all, physicians of the period ascribed great importance to air, smell and climatic conditions as determining factors for health and as causes for disease. ${ }^{25}$

Preparing the patient made inoculation a time-consuming procedure. The treatment of the Danish Crown Prince Christian (later Christian VII) was, for instance, reported to have taken 84 days. $^{26}$ Medical as well as more popular literature on inoculation gives much attention to the preparatory procedures. The prescribed regime normally consisted of purgings, ie. emetics and laxatives, combined with a special diet. The idea was to adjust the constitution of each patient to the imminent inoculation. Consequently the regime applied, eg. the number of clysters to be given, would vary according to the constitution - or 'temperament' - of the patient. ${ }^{27}$ A person of phlegmatic constitution needed different preparations than a sanguine individual. Tissot advises against bleeding, unless the patient has a very blood-rich constitution. Women are usually inoculated immediately after their period, hence they do not need to be bled. Enemas, on the other hand, are absolutely necessary. ${ }^{28}$ Kirkpatrick is vehement that the diet is fundamental because it produces changes in 'our Fluids and Solids' that are gradual and hence 'without Violence to the Constitution'. ${ }^{29}$ During a period of six weeks - or even two months in the cases of very unfavourable dispositions - the patient ought to follow a regime of very light food. Kirkpatrick gives detailed descriptions fit for different constitutions, the most demanding one being that of 'black jaundice' (black bile).

The procedures were thought to call 'for all the Caution as well as Knowledge, of the Physician'. ${ }^{30}$ Knowing this art well, however, 'every ingenious and experienced Physician, who has considered this Matter well, may have sufficient reason to infer, that on availing his Patients of all good Circumstances, Persons of naturally unpromising Temperaments, and less convenient Ages for the accidental Disease, may have a reasonable Expectation of passing very tolerably through that by Inoculation'. ${ }^{31}$ Children were generally thought to need less preparation than adults: a few days of diet and one or two mild purgings were generally held to suffice. ${ }^{32}$ Nonetheless, complications might occur. Kirkpatrick as well as the Swedish physician Lars Montin observe that children frequently suffer from worms. Kirkpatrick's advice is to drive them out with calomel powder and some grains of rhubarb. Older children (from six or seven years) may also be given laxatives like Glauber salt or cream of $\operatorname{tartar}^{33}$

24 Tronchin, op. cit. (note 13); Butini, op. cit. (note 9), $22 \mathrm{f}$.

25 See, for instance, Yves-Marie Bercé, Le chaudron et la lancette. Croyances populaires et médecine préventive 1798-1830 (Paris: Presses de la Renaissance, 1984); Alain Corbin, The Foul and the Fragrant. Odor and the French Social Imagination (Cambridge, Mass.: Harvard University Press, 1986).

${ }^{26}$ Rottböll, op. cit. (note 10), Appendix H, 136-9.

${ }^{27}$ Kirkpatrick, op. cit. (note 10), 224.

28 Tissot, op. cit. (note 12), 49ff.

${ }^{29}$ Kirkpatrick, op. cit. (note 10), 224.

30 Ibid., 238.

31 Ibid., 239.

32 Tronchin, op. cit. (note 13); Rottböll, op. cit. (note 10), 83.

33 Kirkpatrick, op. cit. (note 10), 230f; Montin, op. cit (note 11), 162. 
The attention given to preparations and the large room given to the issue in texts, medical as well as popular, indicate their importance. Preparations loom large in the medical practice that is described, and were equally fundamental to the understanding of what the new method was all about. Kirkpatrick's words quoted above underscore that it was the work with preparations where the competence, experience and art of the physician really entered into the picture. It was the physician's learning that made it possible for him to 'alter the specific Constitution and Stamina' of the patient, and to lead him or her safely through the dangers. This learning and the art it produced are firmly situated within the frames of traditional pathology, with its teachings on constitutions and temperaments, bodily fluids or humours. What can be read from the argument, then, is that the reason why physicians could succeed in their work as inoculators was because they knew how the humours interact inside the body and how they constitute the temperament of each individual. Moreover, this also supplied a reason why inoculation ought to be the privilege of the physicians. Such a claim can be seen as a strategy to stop lay inoculators, but was just as probably an argument directed against surgeons. They were the experts on wounds and operations, and might be called upon to dress the incision made by the inoculator's lancet. Nonetheless, the weight put upon preparations defined inoculation securely as a matter for the physicians.

Roger French has pointed out that when Aristotelian natural philosophy fell into decline during the seventeenth century, medicine was deprived of its philosophical base and faced the risk of being reduced to a mere art of healing. He argues that a number of attempts were made during the eighteenth century to give medicine a new philosophical or scientific base, which did not really succeed until the development of modern anatomical pathology. ${ }^{34}$ The texts on inoculation demonstrate the vitality of the old ways of thinking. In the same way as a modern understanding of blood circulation did not preclude traditional ideas about the usefulness of bleedings, humoral pathology was fully able to incorporate inoculation into the world view it represented. ${ }^{35}$ It dictated the practice of inoculation as well as the way it was spoken about. Both reflected that what was held important and what defined the distinct qualification of the learned physician was his ability to work on the patients' constitutions. This facility by which inoculation was incorporated into traditional pathology made discussions of its working principles superfluous. It also explains why preparation was the issue at stake.

In the second phase, texts on inoculation normally describe the operation itself. The original method used in Europe consisted of making small incisions, normally one on each arm of the patient, and placing a thin thread that had been saturated with variolous matter. The thread was kept in place by a bandage and then removed after about 48 hours. The important development in the 1760s was that the scratches now were made merely cutaneously, and frequently in one arm only. Fresh pus from another patient replaced the saturated thread, and no bandage was needed. The new method reduced the risk of infected wounds, and also produced milder attacks of smallpox, hence increasing the survival rate. Along with these innovations, the preparatory period was shortened. Other new ideas were the extensive use of fresh air and cold drinks during the subsequent illness - the so-called 'cold method'. Pus for the inoculation was now taken as soon as it appeared.

\footnotetext{
${ }^{34}$ Roger French, Medicine before Science. The Business of Medicine from the Middle Ages to the Enlightenment (Cambridge: Cambridge University Press, 2003).

35 Chantal Beauchamp, Le sang et l'imaginarie médical. Histoire de la saignée aux XVIIIe et XIXe siècles (Paris: Desclée de Brouwer, 2000).
} 
It had formerly been thought that too fresh pus did not bring about the desired effect when transferred to another person.

Several of these developments, and not least their organisation into a system, were due to the English surgeon Daniel Sutton. With the motto 'safely, quickly and pleasantly', he made his methods a commercial success in the 1760 s, setting up inoculation clinics in the countryside. Similar innovations were advocated by Thomas Dimsdale who in some cases was also heralded as their inventor. His 1767 book The Present Method of Inoculating for the Small-Pox saw five subsequent editions in as many years. Some physicians worried that the new methods would not produce a sufficient 'cleansing' of the body during the subsequent illness, and also found it hardly defensible to decrease the preparatory period. ${ }^{36}$ Others defended the innovations, even if opinion varied as to which of the elements was the most significant. For some physicians, like Dimsdale and the Sutton family, the new and efficient method resulted in considerable economical gain. Others seem to have adopted the new ways mainly because of the possibility of treating more people cheaply and rapidly, which was important not least during epidemics.

The last phase of inoculation texts describes the care of the patient during the period of illness. About a week after the pus had been inserted the patient would fall ill. Fever normally appeared after seven or eight days, and decreased again when pustules broke out about ten days after the operation. Inoculated smallpox normally gave a smaller number of pustules than the natural version. Their development was nonetheless closely followed, as even inoculated smallpox could lead to fatal cases. A rich crop of pustules circling the scratches where the pus had been inserted was seen as indication of good cleansing: most of the 'poison' of the disease was then thought to be eliminated through the incisions rather than disfiguring the patient's face or other parts of the body. Treatment during the period of illness very much resembled that of the preparatory period. The dietary regime was continued, and so were frequently also the purgings. What was added new from the $1760 \mathrm{~s}$ was the 'cold treatment' during the fever, fundamentally based on the principles described by Thomas Sydenham in 1666. Dimsdale describes it applied to smallpox cases:

Instead of confining the patient to his bed, or his room, when the symptoms of the eruptive fever come on, he is directed, as soon as the purging medicine has operated, to keep abroad in the open air, be it ever so cold, as much as he can bear, and to drink cold water, if thirsty; always taking care not to stand still, but to walk about moderately while abroad. ${ }^{37}$

Spokesmen for the method seem to have considered the introduction of fresh air and cold drinks during illness just as fundamental to the success as the new ways of inserting pus. ${ }^{38}$ Smallpox patients had traditionally been covered up and kept as warm as possible in heated rooms with no airing. Bearing this in mind, the new treatment was a ground-breaking innovation. Its reputation to alleviate or cure the disease was so large that it was even considered to save lives in cases of natural smallpox. ${ }^{39}$ Moreover, the 'cold treatment' agreed well with the neo-Hippocratic medicine of the period. Their common base in principles of humoral pathology was also what made the regimes for preparation and the subsequent care of the patient so similar. What mattered was to work on the constitution of the patient during preparation to make the body fit for the imminent treatment and during

\footnotetext{
${ }^{36}$ Montin, op. cit. (note 11); Anne Eriksen, 'Speaking about disease. Provincialläkare Lars Montin and the inoculation of smallpox'. Tidsskrift for kulturforskning, 9, 1 (2010), 57-74.

${ }^{37}$ Dimsdale, op. cit. (note 12), 35f.

38 Ibid.; Montin, op. cit. (note 11).

${ }^{39}$ Dimsdale, op. cit. (note 12); Montin, op. cit. (note 11); Rottböll, op. cit. (note 10).
} 
illness to help it regain its normal, healthy balance of humours. Another reason for this similarity was that smallpox itself was seen as a purging of the body, making it sensible to let the treatment consist of remedies aimed at aiding this process both before and during illness: purgings and bleedings. The idea is, for instance, expressed by Dimsdale when he terms the inoculated matter a 'purging medicine' (above).

Notions of illness as purgings were central to humoral pathology in general, but had specific implications when it came to smallpox. La Condamine begins his influential treatise in defence of inoculation by describing smallpox as 'a terrible and gruesome disease, whose seed we carry in our blood' ${ }^{40}$ The understanding of the cause of smallpox as something inherent in the individual also forms the basis of his answer to the objections against the new method. It is not correct, he contends, that inoculation means inflicting disease on persons who would otherwise not have been attacked by it. Only those who can have smallpox get it by inoculation. 'The one who does not have the growth or seed of smallpox within him does not suffer more than an operation smaller than a bleeding' but even he will gain the freedom from worry and fear to be taken ill. ${ }^{41} \mathrm{In}$ his discussion of the efficacy of inoculation to protect against future attacks, la Condamine argues that even a person who has had natural smallpox in a very light way may suffer a new attack if the illness has 'insufficiently brought forward the seed or growth that make smallpox break out'. ${ }^{42}$ Tronchin quotes la Condamine's assertion that 'smallpox is inevitable to the majority of persons', ${ }^{43}$ and thus seems to share the understanding. The Swiss physician Jean-Antoine Butini expresses the same ideas more explicitly, explaining that the 'foyer' of smallpox is brought into us at birth. It does not in itself harm the body, but it remains there through our entire lives if it is not exhausted and eradicated through a smallpox attack. Epidemic and contagious 'impurities', miasmas, set this matter into motion, which is what causes the disease. ${ }^{44}$ Even if Butini admits that the exact localisation of the smallpox seed has not been identified, he is able to present a quite detailed explanation of how the infected matter is produced in the blood and gradually seeks its way out of the body, causing pustules and penetrating the skin. ${ }^{45}$ The extreme consequence of this view was an understanding of smallpox as a process similar to secondary dentition or menstruation, and a part of the biological development of the individual. Kirkpatrick argues against this stance, which had been defended by the German physician and philosophe J.G. Hahn in a treatise from 1751. ${ }^{46}$ A main argument against the theory was that if the 'seed' or 'poison' of smallpox was inherent in all human beings from birth, the disease would exist in all historic periods and in all parts of the world - which it did not. The objections did not, however, imply that Kirkpatrick had a very different conception of the cause of smallpox. Even he considered it to be caused by some impurity in the blood, but he was not able to identify its precise location, quality or origin. ${ }^{47}$

The firm rooting in humoral pathology had important implications for the understanding of inoculation. As has already been pointed out, the method could easily be incorporated into the range of purgative means that were already at the disposal of the competent

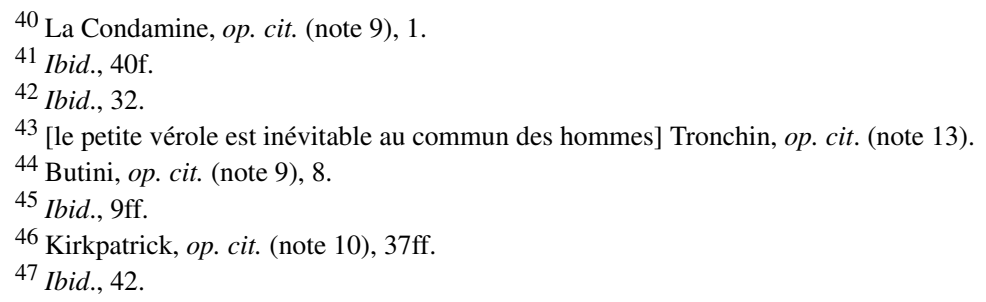


physician. Whether smallpox was considered the necessary cleansing from congenital impurity or as a purging of another kind of pathogenic poison, inoculation was a tool to carry out the process in a more controlled and less dangerous way than the natural disease. Moreover, humoral pathology implied a focus on the patient rather than on the disease. The physician had to come to terms with the constitution of the individual patient, and use his skills to temper it: healing a sick person meant repairing the disturbed balance and harmony of his or her specific constitution, and inoculating to adapt the patient's constitution to the onslaught of smallpox in the most benign way. Historian of medicine Anne Kveim Lie has pointed out that eighteenth-century medicine always saw the state of illness in a body as individual in principle, and argues that this also lay behind the opposition against panaceas offered by quacks: it was not so much caused by a disbelief that all diseases could be cured by one and the same remedy as by a fundamental reluctance to accept the possibility that all patients could be cured by the same treatment. ${ }^{48}$ These two factors - understanding smallpox as a near-unavoidable purge, and a concept of illness and health centred on individual constitutions - did not merely help to shape the way inoculation was integrated into existing medical thought in Europe. They also explain why ideas of defeating, or even eradicating, smallpox as a disease were very far from a necessary consequence of the new technology.

\section{When to Inoculate?}

The freedom to choose the most suitable time and conditions to expose oneself to smallpox was heralded as one of the main advantages of inoculation. Nonetheless, it seems that burgeoning epidemics have most often spurred the interest in inoculation. ${ }^{49}$ Available accounts of actual practice indicate that emerging epidemics were normally the catalyst for introducing inoculation into a region or town. ${ }^{50}$ A detailed description can be found in one of the appendices to Rottböll's treatise. The Danish studiosus medicus Georg Wilhelm Barfoëd had received a letter of inquiry from the authorities about his practice as an inoculator in Jutland in the mid-1750s. One of the queries concerned the number of persons he had treated, and Barfoëd had to admit that he did not know. The young man had been visiting his friend, the vicar of Gunderup in Jutland, when a raging epidemic prolonged his stay and made him seek recourse to the method that he so far knew only from reports and textbooks. People from all parts of the region flocked in great numbers to be treated, one family succeeding the other, all with their children. Barfoëd was deeply aware that he was running in a race that he was not sure he could win. The challenge was to inoculate the children before they fell prey to the epidemic, and Barfoëd was emphatic that he could not always know if the disease was caused by inoculation or by natural smallpox. The operation itself, on the other hand, was uncomplicated and 'so easy, that I have at times executed it on some while they were asleep'. ${ }^{51}$ This was obviously not the time for considering the air and the season, nor for elaborate preparations.

More metaphorically, a similar situation is evoked in the Vicar Axel Smith's text advocating the use of inoculation among Norwegian peasants. He paints the image of a

\footnotetext{
48 Anne Kveim Lie, 'Radesykens tilblivelse. Historien om en sykdom'. Dr med. thesis (Oslo: University of Oslo, 2008), 172f.

${ }^{49}$ Deborah Brunton, 'Smallpox Inoculation and Demographic Trends in Eighteenth Century Scotland', Medical History, 36 (1992), 407.

${ }^{50}$ For instance, la Condamine, op. cit. (note 9), 12, 15, 17; Rottböll, op. cit. (note 10), Appendices.

${ }^{51}$ Rottböll, op. cit. (note 10), Appendix E, 120.
} 
group of people settled on a plain that each year is submerged by a powerful flood of water, killing off many of their number. Then the group obtains access to a raft. Those who climb on are saved from the flood, while those who refuse perish as before. Smith was among the authors who relied heavily on Cramer's argument (above) to refute religiously based objections to inoculation. He concludes that only fools refuse to use such a life-saving remedy that the raft represented, and that rejecting the new tool that God has given us to save us from smallpox is equally foolish or even impious. ${ }^{52}$ Even here, it is obvious that acute risk is what makes inoculation attractive. The risk occurs on a regular basis; Smith describes the flood as an annual event. Nonetheless, the raft is not introduced to be prepared for the flood (or prevent it from coming), but to save lives when the water mass comes flooding.

Smallpox epidemics were frequent, and in large cities the disease was endemic. It is possible that the constant availability of fresh pus this produced may have made inoculation less dependent on epidemics in the large cities. Children (and others who had previously not been exposed) would not live long before the risk of catching smallpox was imminent. This was why smallpox was considered a children's disease, and also why children were the main target for inoculation. Going through life without being stricken by smallpox was unusual, save in very isolated areas. Here an epidemic would have correspondingly disastrous effects on a population not protected by acquired immunity. The frequency of epidemics and the omnipresence of the disease was one reason for the belief that smallpox was due to an impurity congenital to all humans - the illness appeared unavoidable. This also served to blur the distinction between understanding inoculation as a prophylactic, ie. a means to avoid illness sometime in the future, and as a remedy for addressing an acute threat. To most people, the threat of smallpox was too imminent to invite long-term perspectives.

During an epidemic, inoculators would work hard to save as many people as possible, struggling to forestall the disease in the way Barfoëd described (see above). To judge from the reports of Barfoëd and others, the work also did not meet with much popular resistance during epidemics. In such periods, people rather flocked to have their families treated. ${ }^{53}$ It is significant to note, however, that for a long time this was conceptualised in terms of saving lives, not of stopping the epidemic. Smith does not present the raft in his parable as a means to prevent the flood from coming, but as an aid to survive it. One reason was the understanding of smallpox as a cleansing agent. For those subscribing to the view of smallpox being due to congenital impurity, such as la Condamine, Tronchin, Hahn and Butini, the idea of eradicating the disease, or even stopping an epidemic, would be paradoxical. However, even without this specific belief, humoral pathology with its understanding of disease in terms of the individual had similar implications.

Another reason for the fundamentally idiosyncratic approach was the understanding of epidemics and contagion. The eighteenth century is generally considered to be the heyday of miasmatic theories, implying that epidemic disease was seen as caused by impurities in the air. In the case of smallpox, the miasmas were thought to activate the 'poison' in the individual. People who had already been cleansed of it had nothing to fear, but for others the miasma would set off the disease. Butini ascertained that smallpox was epidemic and contagious. The disease was produced by a certain impurity in the air which may be

\footnotetext{
52 Smith, op. cit. (note 13), 4f.

53 Rottböll, op. cit. (note 10), Appendix E, 120.
} 
more or less malignant and more or less abundant. ${ }^{54}$ It is contagious through contact with patients, but represents a threat only to persons not yet cleansed of their impurity. ${ }^{55}$ Tissot defines smallpox as contagious in the following way: 'Diseases whose exhalations, or those from the humours, when they are introduced into healthy bodies, will give the same disease, those are the ones that are called contagious'. Nonetheless, different constitutions as well as changes in their humoral balance mean that different persons will be affected by the contagion in very different ways. ${ }^{56}$ Hence, smallpox will be more dangerous to some constitutions or temperaments than to others. Tissot also argues that the main factor setting off an epidemic will be infected air. ${ }^{57}$ In some cases the 'bad air' of the miasma will produce particularly malignant cases of smallpox, for instance when it occurs during very warm summers. ${ }^{58}$ For this reason, smallpox is a more dangerous disease in southern France than in the northern regions, according to Tissot.

The implication of these arguments concerning the causes and workings of epidemics is that even during an epidemic, illness will vary considerably according to the particularities of the individual, the season and the location. Moreover, the internal causes, ie. the inherent impurity together with the patient's specific constitution, are far more important to the development of each case than the external cause that sets off the disease.

The emphasis on the individual did not impede ideas of mass treatment. The aim was to save as great a number as possible, not least children. Nonetheless, the argument for mass treatment built on other premises than those of modern vaccination propaganda. There were no ideas of herd immunity. Even inoculators who proudly could claim to have treated a very great number of persons seem for a long time to have conceptualised this solely as a matter of individual lives. French historian Catriona Seth has pointed out that even if inoculation was argued to serve 'the common good', for a long time this was conceptualised in terms of individuals, not institutions, and even less in terms of nations or states. ${ }^{59}$ The number of lives saved was identical with the number of individuals treated. Butini argues that inoculation 'will save the life and health of a large number of people, who will succumb to smallpox without it, or who will suffer miserably from the effects of the disease'. He goes on to state that inoculation will not merely prevent a decrease in population, but also diminish the costs for poor relief: the number of disabled and fatherless persons, unable to provide for themselves, will be reduced. ${ }^{60}$ Cramer describes inoculation as a 'means to the conservation and prolongation of our lives'. ${ }^{61} \mathrm{In}$ his article in the Encyclopédie, Tronchin's argument on the advantages of inoculation is centred on accounts of smallpox mortality in a number of European cities which he compares to the reduced mortality after the introduction of inoculation. ${ }^{62}$ The aim of inoculation was to bring as many people as possible safely through the onslaughts of a practically unavoidable epidemic disease. When speaking of the future effects of the method, Tronchin expresses

${ }^{54}$ Butini, op. cit. (note 9), 20.

55 Ibid., 8.

56 [Il y a des maladies telles, que les exhalaisons qui sortent des corps qui en sont atteints, ou quelques unes de leurs humeurs, introduites dans des corps sains, leurs donnent la mème maladie: ce sont celles qu'on nomme contagieuses] Tissot, op. cit. (note 12), 32f.

57 Ibid., 103.

58 Ibid., 16.

${ }^{59}$ Catriona Seth, Les rois aussi en mouraient. Les Lumières en lutte contre la petite vérole (Paris: Éditions Desjonquères, 2008).

${ }^{60}$ Butini, op. cit. (note 9), $30 \mathrm{ff}$.

${ }^{61}$ Cramer, op. cit. (note 13), 36.

62 Tronchin, op. cit. (note 13). 
his strong hope that enlightened thought will triumph, and inoculation will become a general practice. Mortality will then be reduced. He does not argue that the disease will disappear.

Similar considerations are found in numerous texts. ${ }^{63}$ People who have been inoculated will not succumb to an early epidemic, and hence increase their chances of living to old age, the argument goes. The temporal span of these considerations is the individual life. Only rarely are other kinds of future effects discussed, and even here the focal point is the individual rather than the population. The argument is that saving one life through inoculation also means saving the children, grandchildren and so on that this person might have in the future. In this way the argument even includes people who have not yet been born, but these individuals are always conceptualised as the offspring of actual, living persons. A similar argument may be presented in more general terms when inoculation is depicted as a patriotic means to increase the population, not merely to prevent its decrease. In these calculations the consequences of inoculation have been lifted from the individual to offspring and lineage. The potentiality of the new method is nonetheless conceptualised in the organic and quite concrete terms of generational succession, not generalised into more abstract ideas about population or society. Moreover, the emphasis remains on individual persons rather than on the disease.

\section{Risk and Probability}

Comparing smallpox mortality to that caused by inoculation was a key part of the proinoculation argument. The procedure demanded quantitative information. The questions posed to Barfoëd by the authorities in Copenhagen (above) considered the number of people he had treated and the portion that had developed fatal cases. Barfoëd could proudly report that none had died from his treatment. Authors who were not themselves practitioners reported the results of others. Among these, the work of the English doctor James Jurin held a special position and was cited as an authority. In a series of pamphlets from the 1720s he had published reports that systematically compared 'the Danger of the Natural Small Pox, and of that given by Inoculation'. In Philosophical Transactions (1722-23) he provided an overview of the number of people who had been inoculated in England, based on reports from a number of surgeons and physicians. From the 182 cases reported, Jurin had calculated that the risk of dying from inoculation was 'one out of 91'. ${ }^{4}$ The second part of his work was based on a comparison between this result and the figures that could be read out of the annual Bills of Mortality, going back to 1667. Jurin had found that the proportion between those who died from smallpox and the total number of burials remained very nearly the same for the years he investigated. He went on to calculate the 'hazard' of dying from smallpox in different periods of life, also noting that those who die without ever having had smallpox were mainly very young children. Jurin was then able to conclude:

Allowing therefore, that out of every 1000 Children that are born, 386 die under one or two Years of Age, without having the Small Pox, and 72 do some time or other die of that Distemper; it follows, that the Hazard of dying of it, to the remainder of Mankind, above one or two Years of Age, who are all supposed

${ }^{63}$ For instance, la Condamine, op. cit. (note 9) 13ff; Cramer, op. cit. (note 13); Gatti, op. cit. (note 12).

64 James Jurin, 'A Comparison between the Danger of the Natural Small Pox and of that given by Inoculation', Philosophical Transactions, 32, 374 (1723), 215. 
to undergo that Disease sooner or later, is that of 72 out of 614 , or nearly 2 out of 17 , so that no more, than between 7 and 8, can recover from that Disease, for one that dies of it. ${ }^{65}$

Jurin's work was carried out in the tradition of John Graunt, the first to use mortality bills to develop statistical information on public health. ${ }^{66}$ Jurin supplemented this information with reports that he systematically collected from inoculation practitioners throughout the country. The article also presented his concerns over method. Jurin was very much aware that the risk of dying of smallpox varied during life, and endeavoured to incorporate this fact into his calculations.

Jurin's work was frequently quoted by the authors whose texts are investigated here. What captured the most attention were his conclusions and the figures he presented, while his method of collecting information and his concerns over method and calculations generally were ignored. Even when numbers and figures from his work are cited correctly, the emphasis on them alone serves to alter the perspective somewhat. Cleansed of Jurin's original methodological reservations, the numbers stand out as witnesses to unwavering truths. Some authors supplemented Jurin's numbers with similar information from their own cities or countries, though frequently without making it clear from what sources the numbers were abstracted or how the other calculations had been carried out. Others reduced the figures and comparisons to thought experiments or metaphors. After having quoted Jurin and others who compare smallpox mortality with that of inoculation, la Condamine declares that "even if there may be some confusion in the numbers we have presented, the conclusion cannot be any other ..., and one sees that there is a great difference between the danger one runs in the two cases, and that inoculation keeps all its advantage and excellence'. ${ }^{67}$ La Condamine's own text contained no tables or statistics, and his use of numbers obviously owes more to rhetoric than to mathematics. ${ }^{68}$ The numbers become metaphors.

On the one hand, then, there are strong grounds for claiming that smallpox and the debate over inoculation represented one of the very first examples of statistics used in matters of public health. ${ }^{69}$ Correspondingly, inoculation was among the earliest practical applications of the new calculus of probability, as it was developed from the $1660 \mathrm{~s}$ onwards. ${ }^{70}$ On the other hand, it may be worthwhile to look more closely into the use of numbers, accounts and (more or less rudimentary) statistics in the pro-inoculation literature. What kind of meaning did the numbers carry, and how were the risks and probabilities they referred to understood?

Problems presented by games of chance were central to the new ideas of probability, developed by the mathematicians Pascal, Bernoulli and others. Questions of fair contracts, annuities and insurance were other early fields of probabilistic reasoning and application. ${ }^{71}$ Lorraine Daston has argued that such problems not only were the testing grounds for the new calculus, but also deeply influenced the new ideas about what probability was all about. She points out that what was developed by mathematicians and philosophes was a calculus of expectation rather than one of probabilities, and that

65 Ibid., $220 f$.

${ }^{66}$ Rusnock, op. cit. (note 7).

${ }^{67}$ La Condamine, op. cit. (note 9), 51.

68 Rusnock, op. cit. (note 7).

${ }^{69}$ Ibid.; Brunton, op. cit. (note 49); Seth, op. cit. (note 59).

${ }^{70}$ Lorraine Daston, Classical Probability in the Enlightenment (Princeton, NJ: Princeton University Press, 1988).

${ }^{71}$ Ibid.; Rusnock, op. cit. (note 7); Ian Hacking, The Emergence of Probability (Cambridge: Cambridge University Press, 2006). 
ideals of fair games and contracts as well as equal expectation were taken as the point of departure. ${ }^{72}$ It can be added that seeing probability this way also implied taking the individual's perspective. Probability came to concern the individual's risk or chance of loss or gain. This even concerned inoculation. Submitted to probabilistic reasoning, accounts and calculations concerning inoculation were not read as attempts to ascertain the effects of the method among a population at large, but to estimate a specific person's chances of survival.

Historians of the modern ideas of probability have pointed out that the term 'risk' did not come into general use until the early eighteenth century. ${ }^{73}$ Before this the usual terms were 'providence', 'luck' or 'fate'. ${ }^{74}$ Jurin and other eighteenth-century pro-inoculation writers generally preferred the word 'hazard' when they compared the dangers of natural and inoculated smallpox. The situation is even clearer in a much-quoted passage by la Condamine. Tronchin reproduced it verbatim in the Encyclopédie:

It is an enforced lottery, in which we are involved despite ourselves: each of us has his ticket, the later it is drawn, the more the danger increases. In Paris, fourteen hundred tickets are drawn each year, whose prize is death. What does inoculation mean? The conditions of this lottery are changed, the number of unlucky tickets reduced: one of seven, and in the best climates one of ten, used to be fatal, it remains not more than one of three hundred, one of five hundred, soon it will not be more than one of one thousand - there are already examples of this. ${ }^{75}$

The imagery very explicitly evokes the close relationship thought to exist between inoculation and the games of chance so central to probabilistic reasoning. The use of quantitative material concerning inoculation thus served to strengthen the focus on the individual and his/her luck, rather than to weaken it through an emphasis on the epidemic in itself. Initially, quantification came to be perceived as a means to predict the risk or chance of the individual in the very literal 'lottery of life' conjured up by la Condamine.

Quantification was nonetheless among the factors that contributed to new ideas about smallpox and changed the understandings of the future potentiality of inoculation. Andrea A. Rusnock has pointed out that once something has been turned into numbers, it can easily be compared. For this reason, decisions about what to count are vitally important: 'Essential to quantification - broadly conceived as the process of assigning numbers to represent things - is categorisation. In order for Jurin to quantify the success of smallpox inoculation, he had to develop categories to enumerate'. ${ }^{76}$ Rusnock shows how Jurin worked to draw quantifiable information from the reports he received from local medical practitioners. Similar efforts - as well as the problems to be encountered - can be found in Rottböll's treatise. ${ }^{77}$ A number of the reports he published as appendices to his own text reflect the respective authors' greater interest in the social standing of the patients

\footnotetext{
72 Daston, op. cit. (note 70).

${ }^{73}$ Ibid.; Hacking, op. cit. (note 71); Kristiina Savin, Fortunas klädnader. Lycka, olycka och risk $i$ det tidligmoderna Sverige (Lund: Sekel bokförlag, 2011).

74 Gerda Reith, 'Uncertain Times. The Notion of "Risk" and the Development of Modernity', Time \& Society, 13, 2/3(2004).

75 [C'est une loterie forcée, où nous nous trouvons intéressés malgré nous: chacun de nous y a son billet: plus il tarde à sortir de la roue, plus le danger augmente. Il sort à Paris, année commune, quatorze cent billets noirs, dont le lot est la mort. Que fait-on en pratiquant l'inoculation? On change les conditions de cette loterie; on diminue le nombre des billets funestes: un de sept, \& dans les climats les plus heureux, un sur dix étoit fatal; il n'en reste plus qu'un sur trois cent, un sur cinq cent; bien-tôt il n'en restera pas un sur mille; nous en avons déja des exemples] Tronchin, op. cit. (note 13).

76 Rusnock, op. cit. (note 7), 59.

${ }^{77}$ Rottböll, op. cit. (note 10).
} 
than in their actual number. The inoculators who wrote the reports cite names and titles of their most distinguished patients, and lump the rest into entries like 'and a flock of peasants' children'. Rottböll himself strived to transform the illustrious names of princes and counts into numbers. The groups of unnamed poor remained problematic, not due to their lack of social standing but because they had not been counted and did not represent numbers. The work that goes on in his texts gives a very clear illustration of the process that Nicolas Jewson has called the 'vanishing of the sick man from medical cosmology'. ${ }^{78}$ This kind of work not only produced tables that deprived individual patients of their names and said nothing about their social standing, but also disregarded the particularities of each case. Accounts and statistics had little room for the particularities of constitution, climate and season, or for details of the careful and individually adapted procedures of preparation intended to produce gradual changes in the patient's 'Fluids and Solids'. Quantification contributed to objectifying disease and making it possible to speak about it without speaking about specific patients.

The changes in inoculation techniques that happened in the 1760 s enhanced this development. Some of them were caused by the urgency of epidemics, as in the case of Barfoëd (above). Others were the results of theoretical considerations, as with the "cold method' advocated by Sutton and Dimsdale. The simplification of preparations led to an understanding that most patients could be treated in a similar way. In his book on the "new method' Dimsdale was very emphatic that with minor adjustments it could be applied to all patients, given that their general state of health permitted inoculation at all. ${ }^{79}$ Dimsdale's book was above all a manual describing how the successful doctor should proceed. It did not go into theoretical considerations on the nature of the disease or the workings of inoculation. Moreover, it can also be read as a piece of marketing claiming Dimsdale as the inventor of the method that was also used by the Sutton family, and in both cases brought considerable commercial success due to the private inoculation houses that were established. Nonetheless, the new methods would hardly have been conceivable without the medical debate on the nature of smallpox.

Was the impurity that produced smallpox congenital and general or was it acquired on an individual basis? And which were the most decisive causes of the disease - the external or the internal factors? The two medical treatises investigated here, by Kirkpatrick and Rottböll respectively, both discuss the matter, and both tend to put greater weight on the external causes. What makes them particularly interesting is that adherence to traditional miasmatic theories about epidemics only plays a minor role. Both these physicians seem to conceptualise epidemic disease in somewhat new ways. Kirkpatrick gives much attention to the question of contagion and how it arises. He nonetheless concludes that the 'poison' of smallpox (the exact quality of which he declares himself unable to explain), would not be infectious if it did not meet some predisposition in the patient's body. ${ }^{80}$ One argument in favour of this stance is, according to Kirkpatrick, that persons who once have contracted smallpox never will be attacked by the disease again: when the internal cause or poison once has been cleansed out, the contagion can do no harm. Rottböll also gives considerable attention to the question of causes. Smallpox is among the diseases that are produced solely through contagion, he writes, but a certain predisposition in the body is

\footnotetext{
78 Nicolas Jewson, 'The Disappearance of the Sick-man from Medical Cosmology, 1770-1870', Sociology, 10 (1967), 225-44

${ }^{79}$ Dimsdale, op. cit. (note 12).

${ }^{80}$ Kirkpatrick, op. cit. (note 10), 28.
} 
also required. He points to the fact that during an epidemic, some patients develop mild cases, while others die from the disease. The difference is due to individual constitution. Nonetheless, Rottböll also argues that the contagion itself may vary between epidemics. ${ }^{81}$ In this way, Rottböll's argument is very close to defining the contagion as the only cause of smallpox, while the traditional 'internal causes' merely contribute to the severity of the case. His text illustrates how the debates over the internal as opposed to the external causes of the disease gradually served to move the causal factors from the individual body to the contagion. Together with the realisation that the procedure of inoculation did not require much individual adjustment, this move contributed greatly to an understanding of the disease as an object or entity in itself that could be investigated and spoken of without involving all particularities of specific cases. With this shift that seems to have occurred gradually from the 1760 s it became possible to conceptualise inoculation as a means to combat smallpox rather than as a way to cure or save individuals.

A very clear expression of the idea that smallpox epidemics might be stopped is found in a text published in France in 1767. In his pamphlet Un projet pour d'anéantir la petite vérole, the physician Antoine le Camus suggested that strict quarantine regulations should be imposed when an epidemic broke out. His argument was that because no effective medical remedy had been found, smallpox must instead be fought with political means. ${ }^{82}$ This argument implies that le Camus did not consider - nor in fact did he even mention - inoculation as a means to combat epidemics. The regulations he suggests are closely related to traditional measures taken to stop epidemics, not least the plague, by a mixture of isolation and flight. Le Camus's proposal does not seem to have had much influence and was not adopted as a programme, either nationally or locally.

In 1778, the physician John Haygarth presented a similar but more elaborated scheme in England. ${ }^{83}$ Advocating the establishment of a 'Smallpox Society', Haygarth wanted to combine quarantine with inoculation. His belief in quarantine regulations was based on a firm conviction that smallpox only spread by contagion. There was no other activating factor for the disease, he argued. The 'rules of prevention' that he proposed would impose very strict isolation on persons infected by the contagion, as well as give 'utmost attention to cleanliness', both during and after cases of smallpox disease. In 1784, Haygarth's text An Inquiry How to Prevent Smallpox was published, and a Smallpox Society was established in Chester. ${ }^{84}$ Despite local success as well as growing international fame, Haygarth's ideas were not developed into the national programme that he himself advocated. Musing over the reason for this, Christopher Booth writes that Haygarth's ideas were eclipsed by Jenner's vaccine only a few years later. ${ }^{85}$ Correct as this observation may be, it can also be argued that the new ways of thinking about disease and epidemics that were so clearly articulated by Haygarth contributed heavily to Jenner's success and the ways vaccination came to be practised. The idea that a new remedy - in this case vaccination - could be applied as a general programme, aimed at epidemic disease as such, did not stem from the technology itself but had emerged gradually from a number of interacting developments, with Haygarth's ideas as a keystone.

\footnotetext{
${ }^{81}$ Rottböll, op. cit. (note 10), 44ff.

82 Antoine le Camus, Un project d'anénatir la petite vérole (Paris: Loius-Étienne Ganeu, 1767).

${ }^{83}$ Christopher Booth, John Haygarth, FRS (1740-1827). A Physician of the Enlightenment (Philadelphia: American Philosophical Society, 2005).

${ }^{84} \mathrm{Ibid}$.

${ }^{85}$ Ibid., $91 \mathrm{f}$.
} 
The so-called 'general inoculations' that had been held in English towns and villages since the 1770s were an inspiration for Haygarth's plan. The improved methods of inoculation developed by Dimsdale and Sutton not only made the treatment accessible to a greater number of people, but also in some ways tarnished the reputation of the method. While the simpler procedures and safer method may appear the most significant improvements today, the 'cold treatment' was seen as equally important at the time. It implied that the patients were not confined to bed or even isolated, but rather encouraged to seek exercise and fresh air. A consequence of this was an increased number of inoculated and potentially contagious persons circulating amongst the general public. Inoculation came to be accused of spreading the disease, increasing rather than reducing the risk of contracting the disease during an epidemic. Mass inoculations were initiated to counter the situation: when an epidemic threatened, inoculation of all inhabitants likely to be attacked was arranged. The idea was still to stop the epidemic from reaching one's community, and can be compared to traditional plague measures like closing the city gates or stopping ships in the harbour. Nonetheless, it had the potential to create herd immunity. Contrary to these traditional measures of isolation, the general inoculations produced enclaves of people who would not be attacked again: when the next epidemic threatened, only the newborn needed further protection. Initiated as acute treatment in situations of immediate threat, the general inoculations revealed themselves to be veritable prophylactic schemes. Moreover, general inoculations contributed to the understanding that effective protection against smallpox needed to be organised on a collective, societal level; it was a matter for political measures, as le Camus had argued. Even if this happened only late in the century, and shortly before vaccination took much of its role, inoculation contributed to shaping the idea of 'public health' as an political issue.

\section{From Cure to Protection?}

Inoculation was a radical novelty when it was introduced in Europe in the 1720s. During the period that has been discussed here, the years between 1750 and 1775, the method itself underwent important changes, making inoculation less dangerous and more available to a greater number of persons. The close reading of texts has nonetheless demonstrated that inoculation was very far from being conceptualised as a herald of modern epidemic control. Despite the practical improvements, inoculation remained mainly therapeutic. It was seamlessly incorporated into traditional, learned medicine and understood within the frames of humoral pathology and neo-Hippocratic thinking. The old humoral pathology showed itself highly capable of swallowing up the new practice and shaping it according to its own principles: inoculation remained a therapeutics centred on evacuation and cleansing. The medical questions it raised were produced by this context rather than by the novelty or potentiality of inoculation itself.

Neither did new understandings seem to have been produced by the practice as such, but developed along with medical theory more generally, and the weakened understanding of disease as intrinsically individual. Shallower incisions, the use of fresh pus and the "cold method' in the treatment of the patients were not in themselves sufficient to change the fundamental understanding of inoculation. These improvements were heralded as means to make inoculation and the ensuing illness 'safer, simpler and more pleasant', not as a way to avoid smallpox altogether. Far more important would appear to be the discussion over internal versus external causes of disease, enabling perspectives that did not make the individual constitution the key to illness. Alongside this development, the emerging quantitative thinking contributed to changing the understanding of inoculation and helping 
the process of 'the vanishing of the sick man'. The contribution was nonetheless less radical than may be thought. As conceptualised in this period, calculation was more about expectation than about probability, more about luck and hazard than about risk, and far more about individual chance than about general demographic development.

The issue raised by inoculation, as expressed by the eighteenth-century texts examined here, concerned the individual's chances of surviving a dangerous and practically unavoidable illness. By implication, it also concerned what right - or what responsibility - the individual had to intervene in questions of life and death, using a remedy that might in the worst case bring about the death it was supposed to prevent. Even if the religious objections against inoculation were refuted as soon as they were first presented in the 1720s, the texts that have been investigated here show clearly that they continued to be a concern of great importance through the century. The texts advocating inoculation are unanimous in their refutation of religious or ethical objections, but the issue appears nonetheless far too important to be ignored. This cannot be reduced to a simple conflict between conservative theologians and radical philosophes. Firstly, a number of theologians supported inoculation. Secondly, not even radicals touched lightly upon the moral implications of inoculation. Neither is this a matter of (reactionary, superstitious) popular resistance to (scientific) medical innovation. Firstly, again, the risk of producing fatal cases through inoculation was too real to be ignored. Secondly, those opposing inoculation were not ignorant members of the lower classes. What appears from the texts examined above was that the novelty of inoculation - as a new and effective therapeutics - was discussed at great length and very seriously in moral and ethical terms. When looking for the meaning of inoculation to eighteenth-century agents, this complex of ethical, religious, medical and, to some degree, societal concerns is what presents itself. 